\title{
Afro-Chinese partnership in missions. A similar his- tory, a shared vision
}

P F Smit

(UP)

\section{ABSTRACT}

In this article the possibilities of a shared mission vision and praxis between African and Chinese Christians are considered. The possibility of such an endeavour lies in the respective histories of Africa and the Chinese people as well as in a similar vision for the Church of Christ on earth. Powerful forces, of which European colonialism is probably the most important, have shaped African and Chinese Christian's view of mission and the church. After a quick tour through the history of mission in Africa and China, the potentials and piffalls of such a shared mission program are discussed.

In this essay I will mention two partners. The first, dearest to my heart, is Africa, with its people, diverse in many respects, but similar in most. Whenever I think of Africa, I cannot but revel in the thought of its natural splendour and its rich heritage of kingdoms past and present. I also cannot help but see its sad contemporary history of racism, colonialism, exploitation, communism, war, famine, drought and misery. As a Christian and theologian, I cannot think of Africa other than marvelling in the fact that Christianity has reached far and wide, bringing light to this dark continent of mine.

The other partner is of course the Chinese - also diverse in many respects, but similar in most. As is the case in Africa, the history of the Chinese people reaches back thousands of years, witnessing the advent and demise of many kingdoms. The Chinese people have also had its fair share of European racism, colonialism, communism (as is still the case on the Mainland), and natural disasters. Similar to Africa, is also the history of Christianity among Chinese people. Patrick Johnstone cites $6.1 \%$ Christians on Mainland China with a growth rate of $7.7 \%$. This represents \pm 66 million Mainland Chinese Christians alone ${ }^{1}$.

The story of Africa and China (with reference to all Chinese people) is therefore similar in many respects, making them ideal partners in the advancement of the Kingdom of God. In this essay I will focus on Africa, China and the "free Chinese ${ }^{2}$ countries" history of missions. This will evidently lead me to the drawing of some parallels between the African and 
Chinese situations and hopefully to the realisation of the potential of an Afro-Chinese partnership in missions.

\section{AFRICA}

Mission work started on the African continent not long after the founding of the church in Jerusalem. North Africa would play an essential role in the development of Christianity in the following centuries. Some of the most prominent Christian theologians came from this part of Africa, for example Augustine of Hippo, and a number of influential churches also developed in this area of which the Egyptian and Ethiopian Coptic churches are perhaps the most well-known. Unfortunately the expansion of Christianity was restricted to north Africa and to Egyptian, Arabian and Ethiopian sub-cultures in the area. Sub-Saharan Africa remained the dark part of Africa, devoid from the light of the gospel.

As is very often the case, it was political- and economical-more so than missiological reasons, that brought the church to the rest of Africa. "Christian missions in the colonial epoch appeared to be largely a religious accompaniment of the political, economic and cultural expansion of the West" 3 . The church eagerly accepted the challenge posed by the colonial expansion in the 16th century and accompanied the navigators and their troops and the bands of opportunistic merchants to the "ends of the earth". Africa, situated conveniently on the merchant route to the east (round the Cape of Storms), eventually proved to be an asset in itself to the greedy lords in Europe and the race for full colonialisation of Africa was set in motion. This gave the church (or more correctly churches - plural) a relatively free hand in mission work and church planting (in most cases according to the various models of the mother churches in Europe). Thousands of missionaries poured in from Europe to light and relight the torches of the gospel and by the mid 20th century vast areas of Africa were deemed Christianised. The result was ambiguous.

\section{On a positive note}

On the one hand, it should be acknowledged that without the colonialistic thrust of the last few centuries and without the involvement of the church and the enormous missionary fervour which accompanied it, the gospel, in all its facets, would not have reached Africa in so short a space of time. Many Africans received the Good News of Jesus Christ with open arms and where indigenisation of the Gospel occurred, there the church thrived and will, God willing, still grow immensely. Patrick Johnstone estimates 
that $48,1 \%$ of the continent's 557,9 million people are affiliated to the Christian faith in some form or another ${ }^{4}$. Two main by-products of mission work in Africa should also be mentioned in regards to the positive assessment of the Christian mission in Africa.

The first is education. The mission work of the European churches (especially the various Protestant missions with their sola scriptura-principle) was in a sense reliant on education to further mission work. In order for converts to grow in their faith it was necessary to teach them how to read the Bible and in order to do that it was essential to make a thorough linguistic study of the language (and hopefully the culture) of the people. In most cases this venture proved to be the first anthropological and linguistic study of the various peoples of Africa. The importance of vernacular translation of the Bible was that it brought the missionary into contact with the most intimate and intricate aspects of the culture. The practise of translating the Bible and teaching the people to read it invariably led to other areas of study: mathematics, science, etcetera which stimulated the need for enrichment in other areas of life. "They (western missionaries) taught Christian doctrine, but also educated in general. Because missionaries traditionally moved from the West to the rest of the world, Western-style education and technological development became intertwined with the Christian faith"5.

The second by-product of mission work in Africa is the emergence of health services. At first the establishment of health services and facilities were not due to some type of mission-health strategy. Rather "it seems that the introduction of medical services arose first in a small and rather haphazard way in response to the immediate needs of the sick among whom the missionaries were working" 6 . The advent of the great mission hospitals within the mission complexes was a later development due to ambivalent reasons. "At the one end of the spectrum were those who provided a service to the poor simply out of compassion for their needs... At the other end of the spectrum were those who believed that salvation of the soul was all-important, and that hospitals and schools were vehicles through which to bring the Gospel to the sick"7. Nevertheless, it should be stated that without mission work to Africa, the continent would be very much poorer in terms of medical aid and facilities.

Western mission work has thus produced some very wonderful fruits in Africa - fruits which are very often overlooked among African theologians. Mulemfo, reflecting on the Swedish mission in Africa, in an as yet unpublished article, has this to say: "Africans need to start being thankful to God in whatever thing they have benefited throughout the Swedish (and 
Western) missionary endeavour in Africa. The work of the missionaries should be recommended. They took the lead in many things that they have initiated and at the time they tried to collaborate with the natives. Missionaries built schools and hospitals with the intention to convert people but also to participate in the process of uplifting the social conditions of the people" (parenthesis added) ${ }^{8}$.

\section{On a negative note}

The many positives that could be listed, however, are in the eyes of most African commentators overshadowed by the negatives. "Africans, especially through the vehicle of Black and African theologies, have mounted so fundamental and so holistic a critique of the legacies of Western missions in Africa that we must stop and listen before we consider praising the achievements of mission stations" 9 and, might I add, missions in general.

For one thing, Christianity, although spread widely throughout Africa, has proved to be spread relatively shallow. The great emergence of Islam and the success by which its own mission had developed throughout Africa has proved this beyond doubt and as such many lessons can be learned from it. Where Islam has made vast inroads into previous "Christian territory", the reverse seldom happened. J D Holway mentions a few reasons for this phenomenon of which "a defeatist attitude" and "lack of interest" towards Muslims are prevalent. Other reasons for Islam's success where Christianity failed are said to be, for example, the very weak Christian monogamist counter for the Muslim polygamy, and the ease by which a man can obtain a divorce according to Muslim dictates. This, however, is not the full story. J N J Kritzinger lists reasons (apart from European Christendom's apparent inability to inculturate the Christian message for Africa) for the Islam revival, which highlights the numerous failures and sloppy strategic decisions of the European Christian mission to Africa.

Political and ethnic diversification, brought along by colonialism in general and missions in particular, were, and still are, probably the most important reasons: "The anti-colonialist sentiment in independent African states is often accompanied by an anti-Christian sentiment because of the link between colonialism and mission in the past... Within this political climate there is a positive attitude to Muslim states and therefore generally also an openness to Islam"10. J J Kritzinger writing on the Rwandan tragedy as public indictment of Christian mission, highlights the fact that "many Rwandan theologians place the guilt squarely on the shoulders of those missionaries, historians and anthropologists who 'created' the ethnic differences" 11 . 
If this was not enough, Ecclesiastical diversification added to the confusion and threw a very dark cover over the mission to Africa. African Christians learned very quickly from their European church leaders that Christianity was about polarisation of the one Gospel into many diverse and colourful "denominations" (demoninations?) which should try and compete with one another for the largest slice of the African cake. The case of Islam once again proves the more desired way. Compared to the often absurd denominationalism and racially separated churches of Christianity, Islam strongly emphasises the one, classless, "raceless", Islamcultured brotherhood of believers - a sentiment very similar to the so-called ubuntu (one people) idea of the southern African Bantu people in particular and Africans in general. One is often surprised that Christianity appears to be a threat to Islam at all.

The third figure standing beside the emissaries of the European political regime and the Church on the proverbial African beach site, was the envoy of European financial exploitation. In this instance colonial powers probably wrote the saddest chapter in African history - the example of the Congo will suffice: "The most horrible suffering in Bantu Africa, however, resulted from the 'development' of the Congo Free State by large forces of mercenaries, employed by private companies and the Free State Government. Many Africans were forced at gunpoint to abandon their own farms in order to work on great plantations and in mines; those who remained on their own lands were required to produce specified quantities of rubber, cocoa, maize, palm oil, and other cash crops. Those who resisted - and many did - were imprisoned, fined, tortured, maimed or executed"12. What role did the church play in this horrific spectacle? As Murphy notes, it was the individual missionaries who first voiced the plight of the exploited and brought it to the attention of the American and European authorities (excluding that of King Leopold, the usurper of the Congo people, of course!) This was also the case in most of Africa. However, the European missionaries were not totally exempt from combining their missionary fervour with financial by-motives. Sundkler makes this point in regards to Swedish mission to Africa in the following anecdote: "In Sweden, a Swedish vicar, Peter Wieselgren in Västerstad, meditated over news from the East, and wrote: 'Trade shall be the vehicle for mission'"13.

Once the mission was institutionalised and the church with its financial and political structures took over, things turned for the worst especially in those instances - and there were many - where the church was advantaged by government and commerce. South Africa is perhaps the 
most noted example. In return for theological support for governmental policy, the church (Dutch Reformed white church, in this case, and its mission per se) received subsidies and grants-in-aid, not to mention tertiary educational privileges, Sabbath-keeping protected by law, land rights privileges, etcetera.

\section{Africa's Christians indigenise}

Faced with the unfair and dismal prospect of loosing their heritage and culture to follow Christ the European way, many Africans chose not to accept the white man's religion and continue to adhere to the old ways or looked to the prophet Muhammad for spiritual direction. Others, chose a different course: Indigenise Christ and Christ's way into African acceptable norms and means. The result was the spontaneous advent of thousands of "Independent" 14 churches. Especially in South Africa did this process develop extremely quickly. G C Oosthuizen explains: "It is estimated that there are about 12000 of these independent churches with a membership of thirty million on the continent of Africa. However, in no other country is the movement as intense as in South Africa; but in no other country has the African struggle for identity, using Christianity to this end, been as intense as in South Africa"15. The following table shows the phenomenal growth of Africa Independent Churches (AIC's) over the last few decades. Notice the decline of the Methodist church's ${ }^{16}$ impact on the black population of South Africa and the AIC's growth:

\section{Census year}

1946

1951

1960

1970

1980
Methodist\% of black population

12,9

12,2

12,0

11,0

9,3
AIC\% of black population

$$
9,6
$$

18,6

20,1

23

29,3

The AIC's have different church structures, but it does seem that there are three main differences with the European-style churches. Firstly, it seems that the AIC's have chosen for a more hierarchical church structure (episcopalian) over and against the presbyterian system. This is probably due to the hierarchical structure of the traditional tribal system. Secondly, the office of the prophet was introduced in place of the traditional healermedium. Thirdly, the AIC's have succeeded in creating a true fellowship among believers: "The communal ties of the extended family and the clan 
in the traditional community was exceptionally strong. This was broken by the acculturation process and the urbanisation of black people. A vacuum developed and a longing for fellowship, which the independent groups splendidly provided in, especially in the city. Church fellowship now compensate for broken clan community" 1 ?. It is expected that the phenomenon of AIC will expand in the next century and that the old Europeantype churches will slowly shift to the periphery of African Christianity.

\section{ENTER THE CHINESE}

As has been mentioned previously, the contemporary history of China is to some extent very similar to that of Africa. European lust for conquest and exploitation was ready to set China's history on the same course as that of Africa. "Military pressures won men of God the freedom to traverse the country and bring western learning as well as Christian religion to the Chinese people. The foreigners also brought along with them all the paraphernalia of the industrial revolution. By the end of the century (19th century) the old regime was on the verge of collapse, internal weakness having been compounded by external pressures... At this time China seemed so weak and helpless that some Europeans thought that her carcase, like Africa's, would be shared out by the European powers"18. It never happened. China has bore the extreme pain of the Communist conquest under Mao Zedong and the split with Chiang Kai-Shek and the Kuomintang (Nationalist party) in 1949 but apart from the "leasing" of Hong Kong to the British in 1898, China has survived the colonial scramble which Africa had to face. This, however, did not guarantee China free from western influence. Apart from the anticipated involvement in China by western politicians and financial entrepreneurs, the church also could not resist the opportunities presenting itself in the far east.

As early as $635 \mathrm{AD}$ there is evidence of Christian mission work in China. The following 1200 years saw numerous Roman Catholic missionaries working under the various Chinese dynasties. In 1807 the first Protestant missionary, $\mathrm{R}$ Morrison, set foot on the Chinese mainland. As was the case in Africa, Protestant mission work would not really get underway before the involvement of western governments in China's local affairs. This time it would be the trade in Opium (of all things!), which led to the mission expansion in China. A short detour into this portion of China's history would, as in the case of Africa, show the scandalous intertwining of mission work with political and financial gain.

Opium addiction became a problem in China when it was introduced from India in the 17 th century. The Chinese attempted to deal with the 
problem by restricting cultivation and importation of opium in the 19th century. This led to the Opium Wars, as opium trade was highly profitable to Western countries, particularly Britain. The First Opium War stemmed from China's efforts to bar the illegal importation of opium by British merchants. Britain scored an easy military victory. By the treaties of Nanjing (Nanking, 1842) and the Bogue (1843), China opened the ports of Guangzhou (Canton), Amoy, Fuzhou (Foochow), Ningbo (Ning-po), and Shanghai to British trade and residence, ceded Hong Kong to Britain, and granted British extraterritoriality, that is, the right to try British citizens in China in British courts. Other Western powers soon received similar privileges. The Second Opium War, or Anglo-French War, in China also resulted from China's objections to the opium trade. A joint offensive by Britain and France secured another victory. The Treaty of Tianjin (Tientsin) was signed in 1858, but the Chinese refused to ratify it. Hostilities resumed, and Beijing (Peking) was captured by the Western allies. In 1860, China agreed to the provisions of the treaty, which opened 11 more ports, allowed foreign envoys to reside in Beijing, admitted missionaries unconditionally to China, permitted foreigners to travel in the interior (which was also very conducive for mission work), and, unfortunately, also legalized the importation of opium (Grolier Multimedia Encyclopaedia). The so-called Missionary Gunboat Policy introduced after the Opium wars opened even more opportunities for the churches. According to this policy land was mediated to mission agencies by the western powers (who also happened to be involved in the opium and slave trade and alcohol smuggling), buildings and hospitals were erected for them and general security was granted to missionaries. Jerald Gort sums up the situation after the Opium wars quite correctly when he says: "Uiteraard kreeg de zending een belangrijke steun door deze ontwikkeling, hoewel de westerse agressie die daaraan te grondslag lag, door de Chinezen nooit werd vergeten"19. One cannot but see the parallels with the mission in Africa.

What happened to the church in Mainland China after 1949? Arne Sovik notes correctly that the church was not prepared for the political changes that was to follow Mao's successful revolution. The church had become a symbol of western colonialism with the result that, although Religious Freedom was advocated as the official government policy, Christians faced untold suffering and discrimination. Communism also seemed to have had a very positive outcome on a wide variety of aspects of Chinese life, to the further discredit of the church. "...het Partijprogramme, hoe hard het ook leek te zijn, hervorming teweegbracht in de samenleving waarop christenen niets konden aanmerken, hervormingen 
waar de Kerk zelf achter stond 20 ". The success with which Islam conquered vast areas of previous "Christian territory" in Africa because of the tainted bonds between church and colonialism seems to be mirrored in the communist successes in China with regards to the church in the period immediately following the revolution ${ }^{21}$.

Few European missionaries remained in China after 1949. Some were rapidly deported, others were called back by their respective mission organisations. The last one to leave was Helen Willis of the Plymouth Brethren in April 1959. By 1954 all property owned by European Christian organisations (churches, schools, universities, hospitals) were taken over by the new government. From the ranks of the YMCA (YT Wu as director played a very important part) and YWCA the Three Self Patriotic Movement (TSPM) was founded in 1951 to "help the churches to rid themselves from imperialism, feudalism and bourgeois thinking". The ideal of this movement was taken from the mission theology of Rufus Anderson and Henry Venn ("self-governing, self-supporting, and self-propagating") and adapted with a Marxist twist to suit the new situation in China. "This was carried out through denunciation meetings, with attacks on both former missionaries and Chinese church leaders, and through study sessions concerning communist doctrine. Many churches succeeded in meeting these requirements and were permitted to continue Sunday morning services" 22. The Government thus used the TSPM to try and "communistise" the church in China. They failed miserably.

The final and ongoing chapter from the history of the Church in China is truly heart-warming and it has to do with the growth of indigenous "house-church" Christianity in China over and against the western-styled churches that had developed in the colonial era. These churches were free of foreign missionary control and probably started with the independent church movement in 1911 and a similar indigenous movement that grew out of the persecutions of 1922-1927. As a matter of course, it was the only type of Christianity that really showed to be reaching the lost and sustaining the faithful. They "united in informal clandestine prayer and fellowship meetings. For independent and indigenous groups, this transition was very natural. For others, however, who were accustomed to institutional church life, it was a traumatic time. Still they gradually adapted themselves to the new form of house Christianity"23. The house church movement has since grown from strength to strength, surviving many hardships of which the Cultural Revolution of the 1960's and early 70's probably was the most painful. The largest surge of growth in the movement came after 1979. Today the growth rate of Christianity is estimated at 
$\pm 7.7 \%$ largely due to the house church movement ${ }^{24}$.

\section{The Free Chinese}

Let us now turn to "free" China, i e Chinese living in democratic HongKong (till July 1997 that is), Taiwan (The Republic of China), and Singapore of which the vast majority of the population are also Chinese. To go into minute detail on each country's Christian history would take to long. Therefore, I propose to touch only those that are relevant to the topic of this essay.

Taiwan, of course, share most of its history with that of Mainland China ${ }^{25}$ up and till the 1949 revolution when the island of Formosa (Taiwan) became the refuge for the Nationalist Chinese. Little is to be said, other than that the Church in Taiwan has stagnated for 30 years ${ }^{26}$. Reasons for this are given as Satanic bondage, a Resurgence of Buddhism and Taoism, divisions among Christians, the lack of pastors and full-time workers and a low commitment to real Christian service. The most successful churches in the last few decades in terms of growth seem to be the Presbyterian church, especially among the so-called Mountain tribes, and the Assembly Hall Churches (Little Flock), started by Watchman Nee on the Mainland in 1926 and brought to the island after the revolution. Their success, seems to lie in part on their emphasis on small house churches. Very recently the "cell"-church" concept has caught on in churches especially in the south and various home-churches has grown unprecedented over the last few years.

Hong Kong had a small fishing community and was a haven for pirates and opium smugglers before the British occupation. Britain first used the island as a naval base during the Opium Wars with China. By the Treaty of Nanking in 1842, which ended the First Opium War, Hong Kong was ceded to the British in perpetuity. After a second conflict in 1860 , Great Britain acquired Kowloon and Stonecutters Island and in 1898 obtained the New Territories under a 99-year lease. The growth rate of the church in Hong-Kong is somewhere in the region of $3 \%$. The main churches are, as expected, mostly British of origin: Baptist, Church of Christ, Anglican and Methodist. Indigenous churches have not had the enormous impact in Hong-Kong as on the Mainland ${ }^{28}$. The reason may be partly due to the fact that the British are not seen as a threat to Chinese nationalism and have managed to secure British style of government, financial management and also church-culture.

The modern city-state of Singapore was founded in 1819 on the site of a fishing village by the British colonial administrator Sir Thomas 
Stamford Raffles and deeded to the British East India Company in 1824 by the sultan of Johor ${ }^{29}$. In 1826 Singapore was incorporated into the colony of the Straits Settlements. Its advantageous location on the narrow passage between the Indian Ocean and the South China Sea and its free-port status soon turned Singapore into a major commercial centre.

As was the case in most countries in the area, mission work was started by the Roman Catholic church and followed by different Protestant mission agencies. Christianity developed rapidly in the post-World War II period. Between 1950 and 1964, the four major local Protestant church groups - the Anglicans, the Methodists, the Presbyterians and the Brethren - initiated more than 100 new congregations. In the 1950's, four new groups also took root - the Lutherans, the Baptists, the Bible Presbyterians and the Christian Nationals' Evangelism Commission ${ }^{30}$. Today, Singapore has one of the highest standards of living of any country in Asia. It is therefore not surprising that the modern churches in Singapore is characterised by affluence and a tendency towards "bigger and better" and "more and more". The Faith Community Baptist Church of Reverend Lawrence Khong and former Dr Ralph Neighbour is an excellent example. Through their "cell"-church strategy they have built a very powerful and fast growing church. This concept has now been adopted by many of the other mainstream churches, for example the Methodist Church.

\section{A SIMILAR HISTORY, A SHARED FUTURE?}

Granted, there are many differences between the African and Chinese mission, but there are also many similarities and for the purpose of this essay I want to emphasize them in my fostering of a possible shared vision between African and Chinese Christians.

\section{Similar history cultivates understanding}

The history of especially Africa and Mainland China and consequently Taiwan and Hong-Kong runs along parallel lines, especially since the colonial era. In both instances, it was the west which brought the gospel to them and although the message thereof was dear to their hearts, the packaging in which it came was more often than not alien to the indigenous people. The missionaries and/or churches who brought the Gospel were also very often too friendly towards, or in some way advantaged by the European authorities, who in turn also happened to exploit the indigenous people in some way. The cases of the Kongo during King Leopold's tyranny, South Africa during the Apartheid-rule and China, during the Opium 
wars are just a few examples of this painful aspect of mission history. Africa and China have therefore "stood in each others moccasins" at least in terms of their respective contemporary histories.

New faces, new friends

Africans and Chinese have had many dealings with one another in the past. Many Chinese people have made Africa their permanent home. A Segal gives the following statistics (information tabulated):

$\begin{array}{lcl}\begin{array}{l}\text { Country or } \\ \text { area }\end{array} & \begin{array}{c}\text { Number of overseas } \\ \text { Chinese (thousands) }\end{array} & \text { Comment } \\ \text { Africa } & 108.0 & \\ \text { South Africa } & 36.0 & \begin{array}{l}\text { Centres in Johannesburg } \\ \text { Durban. Urban merchants } \\ \text { professions. }\end{array} \\ \text { Mauritius } & 35.0 & \begin{array}{l}\text { Wholesale and retail trade, } \\ \text { professions; intermarriage }\end{array} \\ \text { Madagascar } & 14.5 & \text { Wholesale and retail trade. } \\ \text { Reunion } & 14.3 & \text { Urban small business. }\end{array}$

Others $(\mathrm{N}=29)$

The 29 other African countries are: Nigeria, Seychelles, Lesotho, Tanzania, Ghana, Congo, Zimbabwe, Libya, Angola, Ivory Coast, Mozambique, Zaire, Kenya, Sao Tome and Principe, Liberia, Egypt, Swaziland, Uganda, Sudan, Ethiopia, Gabon, Malawi, Zambia, Togo, Botswana, Morocco, Sierra Leone, Niger, and Cameroon ${ }^{31}$.

These statistics do not, however, give a picture of the enormous potential that Christian Chinese immigrants could have on Africa, not to mention the fruits that could follow Chinese Christian workers in Africa. As two "neutral" ethnic people, Chinese and African Christians could work miracles where European Christians have failed in the past.

\section{The role of the "old religions"}

Another important point of convergence between Africa and the Chinese people is the fact that the so called "old religions" still play a major part in the lives of the people and shackle them to a life of continuous fear of powers and spirits beyond their control. Johnstone estimates that \pm 70 million (15.4\%) people in Africa still adhere to the traditional animistic 
religions of Africa ${ }^{32}$. Living in Africa, I believe that this is a very modest estimate. Millions of nominal Christians in many countries still try and syncretise the old ways with Christianity. G C Oosthuizen, writing on the causes of the independent (indigenous) churches in Africa cites the continued influence of the old religions as a major factor in the establishment of these churches: "Traditional religious aspects such as the ancestor cult, mediatorship, 'eschatology', concept of sin played their role in the formation of these movements" ${ }^{33}$. The old religions also still play a major role in the life of traditional Chinese people. In Mainland China \pm 2.4\% ( 25 million) people still belong to the old religions. In Taiwan "Tribal religions are still practised by remnants of the 10 Aboriginal tribes in the mountains who untill recently were all head-hunting animists. Since 1945 they have experienced mass conversion to Christianity. 70\% of Taiwan's population are also still practising 'a blend of Confucianism, Taoism and Buddhism, with strong emphasis on veneration of ancestors'”. The same is true for Singapore $(52.4 \%)^{34}$.

In a shared mission vision this factor can hardly be ignored. African and Chinese Christians should work together on a strategy with regards to their respective "old religions" to free the people still adhering to them. "The message to the animist must present a God who sent his Son not only to bring salvation from sin (Luke 19:10), but also to destroy the works of Satan"35.

\section{Islam and Communism: shared challenges}

As was noted in sections 1 and 2 both Islam and Communism played and are still playing major roles in African and Chinese countries. Communism has met its demise to a large extent in Africa, although there are still some very powerful communist governments in power (Libia, for example) and some very active communist parties throughout Africa. Communism has also shown a few cracks in Mainland China ${ }^{36}$, mainly because of the evident weakening of orthodox communists in both the USSR and Eastern Europe $^{37}$. Communism has had a huge effect on Christians, both in Africa and China. Both have learned very valuable lessons in dealing with the challenges posed by communism. The same holds true for the vast and/or growing Islamic presence in Africa and countries such as China and Singapore. Here again, African and Chinese Christians should take hands to pose a successful challenge to Islam.

\section{Holistic peoples, holistic Christianity}

Both Traditional African and Chinese people have proven to be holistic in their anthropology and world view. One has only to look at their respective 
traditional religions and healing systems. Christian mission, which is, therefore, not holistic in its approach, always emphasizing only the spiritual aspect of salvation, will never be successful in its aim to transform persons to the image of Christ. "Missionary literature, but also missionary practice, emphasize that we should find a way beyond every schizophrenic position and minister to people in their total need, that we should involve individual as well as society, soul and body, present and future in our ministry of salvation" 38 .

In the more affluent churches of Singapore, Hong-Kong and Taiwan, where poverty and disease are often forgotten, the tendency may arise to forget that salvation for many, many Africans is much more than being sure of their eternal salvation. Chinese Christians, therefore, sensing and knowing the importance of a comprehensive-type salvation and possessing the resources to provide it, are in the advantaged position to bring total salvation to many Africans not yet reached by Christ's transforming power.

\section{Colonial churches to Indigenous cell church}

As was the case in Africa, the European and American mission endeavours resulted in literally millions of people accepting the Good News of Jesus Christ in China. J T Chao reports that by 1949 (Communist revolution) there were an estimated 1.6 million Protestant Christians supported by \pm 13000 Christian workers with 19497 church buildings spread throughout Mainland China. Education and health facilities also benefitted tremendously. At the time of the Communist take-over 13 Christian universities, 211 secondary schools, 46 theological seminaries, 51 YMCA city centres and an unbelievable 262 Protestant hospitals were functioning within Chinese borders ${ }^{39}$. No one can doubt that the colonial era is to be thanked for bringing Christ, and along with the church's mission, education and better health facilities to the people of Africa, China, Taiwan, Singapore and Hong-Kong.

However, it should be stated that mission work was too often coloured by suspicious motives and energized by political and/or economic structures and means foreign to the mission ethic of the Gospel. The heavy involvement of the western Governments in the local affairs of China (and other Asian countries) and the subsequent economic and other exploitation of its resources on the one hand and with the expansion of Christendom on the other tainted Christianity and its mission to such an extent that Asian theologians joined hands with their African colleagues at the 1973 World Council of Churches' Commission on World Evangelism at Bangkok and 
voiced the notion of a "moratorium" on foreign missions loudly and clearly.

The enormous growth of Indigenous churches, both in Africa and in China and recently even in, what I termed, the "Free" Chinese countries, and the decline or transformation of the old "Colonial"-type churches to fit the local religiosity, have shown without a doubt that a possible shared vision should be sought along the lines of small, indigenous gatherings of believers and/or large charismatic congregations ${ }^{40}$. Especially the exploration of the potential of the small, intimate churches should be a priority. Mei-Ling, a native Taiwanese, sums up the desire, I believe, of many African and Chinese Christians:

Sermons, speech after speech... it's not their own lifestyle. They don't feel natural. When I ask my friends or traditional family to come to church, they normally feel embarrassed. But if you invite them to a small group at a family's home, it is easier for them. It is more natural for the Chinese to come to the home and have a meal together than for them to go to church for Sunday worship! In a large group setting, it is easy to remain semi-anonymous. It might also be hard for a newcomer to "break into" the already established group. Keeping numbers to a minimum would help to foster deeper relationships and allow for more interaction on a personal level ${ }^{41}$.

In Africa these small "cells" are found in small informal gatherings in houses or more often outdoors (if the weather permits it). Especially in an urban setting where traditional family structures give way to individualism and a need for socializing and sharing develops, one can expect a very rapid growth of these type of churches. G C Oosthuizen explains: "The independent movements in the cities serve as a means to break the inner tension built up in an atmosphere where individualism prevails". The small groups have some obvious advantages over the old colonial type churches:

Smaller groups are established for the sake of better control. The movements have adapted themselves to the existing structure of the traditional society with the family as nucleus, giving them not only a psychological but also an organisational advantage to the historic churches. They often form small "house congregations", the most familiar concept of the Church amongst independent movements; they are not over-institutionalised bodies. The over-europeanised, over-institutionalised, over-intellectualised churches do not give emotional satisfaction to the African whose approach to worship leaves much room for spontaneity ${ }^{42}$.

With this shared vision of churching found throughout South- and Central America, Africa and Asia, I believe that Chinese and African Christians could make a major contribution to reach the world for Christ if they could work together. The house church-concept as a means of mission was not created by Paul Yonggi Cho or Dr Ralph Neighbour, but by the early church, and was practised in Africa long before the re-introduction thereof 
in Asia. What is needed, though, is a sharing of resources and knowledge and traditions to enrich both Chinese and African Christians.

\section{Partnering, not parenting}

The previous remark brings me to the question of paternalism. If working towards a shared vision in mission, one can ask who plays the part of the parent, the Africans or the Chinese? This is a very important question and one which is not easily answered. In terms of statistics, Africa should at least be acknowledged as the senior partner. $48.1 \%$ of Africa's 558 million people are already affiliated to Christianity in one form or another. Compare that to the meagre $6.1 \%$ Christians on Mainland China; Taiwan's 5\%; Hong Kong's $14.1 \%$; and Singapore's $14 \%$ it is clear who should lead the way ${ }^{43}$. Africa has indeed accumulated a wealth of knowledge, especially in the area of indigenous churching and could be a very valuable teacher to Chinese Christians in many respects. However, Africa is in need of a great variety of Christian expertise that Chinese Christians have developed in the last century. African Christian leaders (especially "cell"/home church leaders) are in dire need of theological training. African Christians are also in need of primary health care facilities, education, and general upliftment and development - all areas in which the "free" Chinese Christians could be of tremendous help.

The relationship should never again be one of parent towards child (Chinese Christians are in any case not in the position to play parent towards African Christians). That type of mission belongs to an era both African and Chinese Christians want to forget. Rather, the shared vision should be spelled out in terms of Partnering, wherein both partners share the vision and responsibilities.

\section{NOTES:}

1 P Johnstone, Operation World, Carlisle (UK) 1993, 170, 265, 487. Taiwan 5\%, growth rate $1.6 \%$; Hong Kong $14.1 \%$, growth rate $3 \%$; Singapore $177.7 \%$ Chinesel $14 \%$, growth $5 \%$.

2 Referring to Taiwan, Hong-Kong, and Singapore.

3 B Sundkler, The World of Mission, Michigan 1965, 120.

4 Johnstone, op cir, 34.

$5 \quad$ E Bruwer, Beggars can be choosers!, Pretoria 1994, 29.

6 C Allwood, "Mission as healing the sick: Christian medical missions in South Africa", Missionalia 17/2 (1989), 115-125.

7 C Allwood, op cit, 115-125.

8 M M Mulemfo, Swedish missionary presence in Africa: Continuity or discontiumuity? (Unpublished article), 1997. 
T S Maluleke, "Some legacies of 19 th century mission: The Swiss Mission in South Africa", Missionalia 23/1 (1995), 9-29.

10 Compare the articles of J D Holway, "Christianity and Islam in Africa - looking ahead", Missionalia 2/1 (1974), 3-16 and J N J Kritzinger, "Islam as rival of the gospel in Africa”, Missionalia 8/3 (1980), 89-104 for a detailed debate on this topic.

11 J J Kritzinger, "The Rwandan tragedy as public indictment of Christian mission", Missionalia 24/3 (1996), 340-357.

12 E J Murphy, The Bantu civilization of Southern Africa, New York 1974, 246.

13 Sundkler, as quoted in Mulemfo, op cir. Unpublished article.

14 "Independent" from the mainstream European-type churches.

15 G C Oosthuizen, "The Africa Independent Church's Centenary", Africa Insight $15 / 2$ (1985), 70-80. This number should be much higher by now but estimates are uncertain.

16 Oosthuizen, Africa Insight, 15/2 (1985), 70-80. Until recently the Methodist Church was the strongest Western-oriented church as far as the black population was concerned.

17 D Crafford, "Uitdagings van die onafhanklike swart kerke en bewegings aan die kerk in Afrika", NGTT 21/2 (1980), 177-187.

18 R Dawson, The Chinese experience, London 1978, 285.

19 J Gort, "De wisselvalligheden van 150 jaren zending in China", Wereld en Zending 4 (1987), 330-338.

20 A Sovik, "Protestanten in China sinds de revolutie in 1949", Wereld en Zending 4 (1987), 302-308.

21 A note of interest concerning the Muslim presence in Communist China: Chinese Muslims are in a much more advantageous situation on the Mainland than Chinese Christians, or Buddhists for that matter. During the Land Reform, for example, many of the mosques were allowed to retain their lands. The reasons seem to lie in history, for example, if it was not for the military assistance of an Arab contingent, sent by the second Abbasid Caliph al-Mansur in $757 \mathrm{CE}$, the T'ang Dynasty would surely have succumbed to the rebel forces of An Lu-Shan. Chinese Muslims, through their scholars (such as Ma Chien, Pai Shou-I and Ch'en K'e-li), are also much more prone to try and syncretise Communism with Islam. Islam, of course, also do not suffer from the same colonialistic stigma as Christianity.

22 D B Barrett (Ed.), World Christian Encyclopedia: A Comparative Survey of Churches and Religions in the Modern World ad 1900-2000, London 1982, 233.

23 J T Chao, "Churches in China: Flourishing from house to house", Christianity Today, 26/11 (1982), 24-26.

24 Johnstone, op cit, 164.

25 The island was inhabited by Han Chinese centuries before the 1949 Chinese revolution and Catholic missionaries had worked there as early as 1621 . The first Protestant mission work was initiated by the Dutch between 1624 and 1662 by the Dutch Reformed Church. The first Protestant missionaries of the present era were English Presbyterians who arrived in 1865. After the revolution many missionaries followed the nationalists to the island and resumed their work there. Today the Presbyterian Church is still the largest denomination with \pm 208000 affiliated members. See Barrett, op cit, 236. 
Johnstone, op cit, 171.

27 The "cell"-church concept is based on the philosophy first mooted by Dr Ralph Neighbour, former pastor and missionary at the Faith Community Baptist Church in Singapore, whose recent growth through cell groups astounded church researchers. Many Asian churches are also catching onto the idea that moving into cell groups will give a kick-start to the sometimes lethargic expansion of the traditional (western-style) church. The most successful is of course Pastor Yonggi Cho's Yoidi Full Gospel Central Church in South-Korea. It boasts $\pm 700,000$ members involved in more than 70,000 cell groups. See JuLan Kim, "In Korea, world's largest church has tremendous political clout", The Freedom Writer (Oct 1995), 3.

28 Two of the fastest growing churches in Hong-Kong are, however, the Spiritual Food Worldwide Evangelistic Mission and the Assembly Hall Churches (Little Flock), both indigenous Chinese churches.

29 Islam is the second largest religious grouping in Singapore after the Chinese religions, comprising of $\pm 15.4 \%$ of the population (Christian 14\%).

30 Barrett, op cit, 615.

31 A Segal, An Atlas of International Migration, London 1993, 128.

32 Johnstone, op cit, 36.

33 G C Oosthuizen, “Independent churches and religious movements - a variety of causes", Testimonium 2/1 (1973), 50-71.

34 Barrett, op cit, 236; See also Johnstone, op cit, 164,170,487.

35 P F Theron, African Traditional Cultures and the Church, Pretoria 1996, 133.

36 The student uprise and the sad events which occured on the Tiananmen Square on June 4, 1989 are painful reminders.

37 A M Ciencialala, The Rise and Fall of Communist Nations 1917-1994, Lawrence, Kansas 1996, 6,7.

38 D J Bosch, Transforming Missions: Paradigm shifts in Theology of Mission, New York 1991, 309.

39 J T Chao, "The Christian mission to the Chinese people", Missionalia 5/2 (1977), 367-368.

40 The house churches of Mainland China, "cell" churches of Singapore's Faith Community Baptist Church and small groupings of the Apostolic Church in Zion in South Africa can be mentioned as examples of the former. Examples of the latter is the Celebration Services of many Asian Charismatic churches and the Zion Christian Church of South Africa.

41 A Tan, Cells unlimited, World Wide Web (http://www.omf.org/eam/ 973_cellsunlimited.htm), 1997.

42 Oosthuizen, op cit, $2 / 1$ (1973), 50-71.

43 Johnstone, op cit, 164,170,265,487. 